\title{
BUDAYA ORGANISASI PEMERINTAHAN DAERAH KABUPATEN TULANG BAWANG LAMPUNG
}

\author{
Kausar \\ Dirjen Pemerintahan Umum Kemendagri dan Staf Pengajar Universitas Nasional Jakarta \\ Email: iesye.kausar@gmail.com
}

\begin{abstract}
ABSTRAK. Setiap organisasi pemerintah memiliki budaya yang digunakan untuk mencapai tujuan. Dalam praktiknya, budaya organisasi tesebut tidak senantiasa merefleksikan budaya dimana organisasi tersebut berada. Dalam riset yang dilakukan di pemerintahan daerah Tulang Bawang ditemukan bahwa budaya organisasi merupakan perpaduan budaya jaringan, budaya upahan, budaya fragmen dan budaya Komunal. Kesemuanya berpadu secara harmonis atau ada pertalian antara satu dengan yang lainnya. Saling memahami satu dengan yang lainnya dalam kehidupan para pegawainya tampak terlihat dalam keseharian karena budaya ditafsirkan sebagai nilai dan kepercayaan. Dengan espaused dan enacted melekat pada kehidupan birokrasi yang mengadopsi kultur lokal piil pasenggiri sehingga kinerja birokrasi dan interaksi menjadi lebih baik diantara para pegawai.
\end{abstract}

Kata Kunci : Budaya organisasi dan pemerintahan daerah

\section{ORGANIZATION CULTUR OF TULANG BAWANG DISTRICT GOVERNMENT LAMPUNG}

ABSTRACT. Each organization as well as governmental organization has its own culture. The culture of each organization is implemented in the aim of obtaining its purpose. However, in the practice, the culture of organization does not always reflect the cultural value where the organization is located. This research has successfully discovered that the culture of organization which is implemented in the local government (regency of Tulang Bawang), lampung is : by combining the types of the culture of organization: network type, hiredworker type, Fragments type and communal type, it means that all those types shall be done in harmony, or in other word, there must be interrelation between one type with others. Either local government or another governmental apparature, along with the society shall consider and understand when the value of sociality and solidarity should be shown. The culture of organization is divided into value and belief. From the view of value, there are two types of value, "espaused values" and "enacted values" which is believed to contribute in improving the performance of the bureaucracy, including the local culture piil pasenggiri. While in the view of belief, the apparature of bureaucracy in the local government can distinguish when they should perform their task and also when they can do interaction.

keyword : Organization Culture and local government

\section{PENDAHULUAN}

Budaya organisasi adalah salah satu faktor yang perlu dibangun di pemerintahan, mulai dari Pemerintahan Pusat, Pemerintahan Propinsi dan Pemerintah an Kota dan Kabupaten, bahkan juga di pemerintahan Desa di Indonesia. Melalui sosialisasi, pelaksanaan dan penetapan budaya organisasilah suatu jalannya roda pemerintahan dapat diharapkan mampu memenuhi harapan dan tuntutan masyarakat dimsns pemerinthan itu dijalankan.
Pemerintahan Daerah mau tidak mau akan bersentuhan dengan budaya, termasuk budaya organisasi yang dijalankan di pemerintahan daerahitu. Sebuah dimensi yang dibentuk sepanjang sejarah dan peradaban yang diakui tidak akan pernah terhapuskan. Penulis mencoba menyajikan sebuah contoh yang paling tidak dapat menampilkan bagaimana sebuah daerah yang memiliki kekayaan budaya khas, yang menjalankan organisasi pemerintahannya sepenuhnya bersandar dengan pendekatan budaya organisasi yang mendukung bagaimana nilai budaya lokal menjadi pertimbangan yang 
begitu diagungkan, diutamakan dan digunakan untuk menata pemerintahan di daerah.

Penelitian ini juga menemukan banyak hal yang bisa dijadikan rujukan pemerintahan daerah lain di Indonesia bahwa sejatinya pemerintahan daerah bisa meningkatkan kinerja pegawainya karena budaya organisasi yang digagas dengan cara yang menggabungkan pastisipasi masyarakat, pegawai dan pemerintah daerah itu sendiri.

Menurut Rasyid (1997: 48), pemerintahan mempunyai tiga fungsi yang hakiki yaitu ; Pelayanan (services), pemberdayaan (empowerment) dan pembangunan (development). Pelayanan akan membuahkan keadilan dalam masyarakat, pemberdayaan akan mendorong kemandirian masyarakat dan pembangunan akan menciptakan kemakmuran dalam masyarakat. Pendapat ini memberikan kesan bahwa peran pemerintah tersebut hanya cocok diterapkan pada masyarakat di negara berkembang yang tingkat keberdayaan masyarakat masih rendah sehingga ketergantungannya pada pemerintah masih tinggi.

Apa yang menjadi fungsi pemerintahan secara umum itu, menjadi fungsi pemerintah daerah juga pada umumnya, artinya dimensi itu menuntut kaidah perilaku dalam berpemerintahan yang diwujudkan dalam penataan budaya organisasi, yang harus menjadi rujukan tiap komponen yang ada didalamnya. Karena itulah penelitian ini berangkat dari sejumlah pertanyaan mendasar: Bagaimanakah Budaya organisasi daalam pemerintahan daerah itu? Dan bagaimana pula pemerintah Daerah Tulang Bawang Lampung Mewujudkan Budaya Organisasi dalam roda pemerintahan Daerah yang dijalankan?

Beberapa studi menunjukkan bahwa Budaya Organisasi berhubungan secara signifikan dengan sikap dan perilaku pegawai. Misalnya Budaya yang bersifat membangun (konstruktif) pasti akan sangant menentukan sikp positif atas pekerjaan yang dijalaninya, ini juga pasti akan terkait dengan tercapainya kepuasan kerja, berusaha melakukan inovasi dalam pekerjaan dan pastinya akan terus mempertahankan dan meningkatkan kinerjanya menjadi lebih baik lagi,

Adanya asumsi sebagian besar masyarakat bahwa budaya kerja organisasi sebagian besar
Pegawai Negeri Sipil khususnya pastinya membuat kajian ini menarik untuk dikaji dengan pendekatan yang mampu menelisik kebenaran asumsi itu, penulis menyajikan sejumlah pendekatan yang mampu menjelaskan bagaimana sebenarnya budaya organisasi pemerintahan di daerah itu dan bagaimana pula budaya organisasi pemerintah Daerah dijalankan di Tulang bawang Lampung.

\section{Budaya dan Budaya Organisasi}

Budaya merupakan konsep dasar dalam antropologi, Kluckhohn (Pace ;1998:90) mengemukakan konsep Budaya yang diterapkan dalam organisasi yaitu:

(1). Perspektif holistik, perspektif ini memandang budaya sebagai cara-cara terpola mengenai berpikir, menggunakan perasaan dan bereaksi.

(2). Perspektif Variabel, perspektif ini terpusat pada bagaimana budaya diekspresikan.

(3). Perspektif Kognitif, perspektif ini menegaskan gagasan, konsep, cetak biru, keyakinan, nilai dan norma "pengetahuan yang diorganisasikan" yang ada dalam pikiran orang-orang untuk memahami realitas.

Reslitas Budaya dalam organisasi akan selalu beriringan dengan tiga kriteria itu dan sesungguhnya tiap orang termasuk yang tidak berada dalam organisasi itu sekalipun dalam mengamati apakah budaya organisasi dijalankan dalam organisasi baik perusahaan maupun pemerintahan. Budaya organisasi juga mempunyai beberapa fungsi, seperti yang dikemukaakan oleh Robbins ( 2003:311) :

(1). Budaya mempunyai peran menetapkan tapal batas yakni menciptakan perbedaan yang jelas antara satu organisasi dengan organisasi lainnya.

(2). Budaya membawa suatu identitas bagi anggota-anggota organisasi.

(3). Budaya mempermudah timbulnya komitmen pada sesuatu yang lebih luas dari pada kepentingan diri pribadi.

(4). Budayqa meningkatkan kemantapan sistem sosial, merupakan perekat sosial yang membantu mempersatukan organisasi itu dengan memberikan standar-standar yang tepat untuk apa yang harus dikatakan dan dilakukan oleh para pegawai.

(5). Budaya berfungsi sebagai mekanisme pembuaqt makna dan kendali yang 
membantu dan membentuk sikap serta perilaku para pegawai.

Apa yang dinyatakan Robbins tersbut masih berlaku dan tentu saja merupakan gambaran yang harus diwujudkan dalam tiap organisasi termasuk organisasi npemerintahan umumnya dan organisasi pemerintah sdaerah khususnya. dalam banyak hal pemerintah daerah tidak bisa disamakan dengan pemerintah pusat, termasuk pola organisasi dan ritme kerja, beban kerja maupun kapasitas dan kemapuan keuangan yang juga mengisyaratkan perbedaan yang tidak seragam. Tetapi satu hal yaang harus disepakati nampaknya, menjadikan budaya organisasi sebagai pijakan pastilah dapat mengantarkan pemerintahan didaerah dan pemerintahnya termasuk rakyatnya mempunyai ndaya saing standar yang diakui ditingkat nasional.

Berdasarkan tife yang harus diikuti, Gofee dan Jones (dalam Robbins: 2003:327) mengungkapkan 4 (empat) tipe budaya organisasi

(1) Budaya jaringan

(2) Budaya Upahan

(3) Budaya Fragmen

(4) Budaya Komunal.

Bila dijelaskan, Budaya jaringan biasanya mengandung konotasi bahwa organisasi yang menganut budaya itu adalah tinggi budaya sosialitasnya, tapi rendah budaya solidaritasnya. Disinilah semua orag dalam organisasi dipandang sebagai keluarga atau sahabat. Semua saling menyukai, mengenal dan menyenangi. Satu sama lain saling berbagi informasi, tetapi semua hal yang selalu terfokus pada nilai persahabatan justru dianggap sebagai sesuatu yang negatif dalam sebuah organisasi. Sehingga toleransi terhadap orang yaang bekinerja jelek juga selalu diberikan, bahkan tidak menutup kemungkinan timbulnya kliknya politik.

Disisi lain, Budaya upahan kebalikan dari budaya jaringan, budaya upahan menganut prinsif rendah pada sosialitas, tinggi pada solidaritas, hal ini tentu saja menuntut agar organisasi fokus pada tujuan, semua orang yang ada didalamnya memiliki semangat yang tinggi untuk menetapkan tujuannya sesuai dengan tujuan organisasinya. Pola bekerja cepat juga dilakukan dan tentu saja raata-rata memiliki kepekaan untuk mencapai tujuan, tetapi tife organisasi yang menganut buaya ini juga memiliki sisi negatif yaitu seringkali timbul perlakuan yhang seringkali mengarah kepada perlakuan yang tidak manusiawi jika hal itu dihadapkan kepada orang yang memiliki kinerja yang dianggap rendah.

Sementara itu, Budaya Fragmen justru meletakan sisi sosialitas dan solidaritas yang sama- sama rendah, artinya, mereka yang menganut paham individualismelah yang berada di organisasi ini, individualis-individualis tadi saling merasakan bahwa meski berada dalam satu organisasi mereka berdiri ssendiri-sendiri. Bagi mereka komitmenlah yang paling pertama dan paling utama untuk setiap tugas dan jabatan yang mereka emban, maka mau tidak mau penilaian terhadap pegawai dilakukan semata-mata hanya berdasarkan kualitas dan mutu kerja, sisi negatif dari tife ini adalah bahwa seringkali saling kritikmengkritik menjadi budaya yang dianggaap cair, wajar dan mutlak dilakukan, prinsif kolegalitas menjadi nisbi adanya.

Pada organisasi yang mengnut budaya komunal, organisasi ini menganut paham antara sosialitas dan sosialitas sama tingginya, jadi antara kinerja dan persahabatan dinilai sama tingginya, orang merasa memiliki organisasi dan sekaligus fokus padda tujuan yang digariskan. Dan pada organisasi seperti inilah pemimpin seringkali tampil menjadi Inspirasi, sekaligus berkharisma. Visi terhadap organisasi dikaitkan dengan jelas dengan masa depan organisasi. Tetapi bukan berarti tipe ini tidak memiliki sisi negatif, karena satu dengan lain seringkali saling mengkonsumsi kehidupan antara satu dengan lainnya.

Untuk menkaji fenomena yang diteliti penulis juga mengutip faktor yang mendasari budaya organisasi dari Kreitner dan Kinicki ( Robbins :2003:97). Yaitu : "nilai dan Keyakinan." Nilai adalah keyakinan yang dipegang teguh dan ditampilkan oleh angota suatu organisasi dalam tingkah lakunya. Sedangkan "keyakinan adalah : pemikiran dan kepercayaan individual mengenai bagaimana dirinya sebagai anggota suatu organisasi itu menjalankan tugasnya dan berinteraksi dengan orag lain. Dua hal ini juga yang nantinya menjadi rujukan peneliti untuk mencari tahu bagaimana budaya organisasi dikabupaten Tulang Bawang sebagai sebuah daerah yang masih begitu menjunjung tinggi nilai budayanya, menerapkan semua hal itu dalam organisasi pemerintahan bernama pemerintah daerah. 


\section{Budaya Organisasi dan Pemerintahan Daerah.}

Paradigma baru penyelenggaraan pemerintahan daerah sebagaimana diatur dalam Undang-Undang Nomor 22 tahun 1999 tentang Pemerintahan Daerah yang sekarang direvisi dengan Undang-Undang Nomor 32 Tahun 2004, menegaskan bahwa titik berat penyelenggaraan desentralisasi diletakkan pada pemerintahan kabupaten dan kota. Hal ini sesuai dengan batasan pengertian tentang desentralisasi yaitu penyerahan wewenang pemerintahan oleh pemerintah pusat kepada daerah otonom untuk mengatur dan mengurus urusan pemerintahan dalam sistem Negara Kesatuan Republik Indonesia.

Perubahan paradigma dalam penyelenggaraan pemerintahan daerah, jelas memerlukan perubahan dan adaptasi yang menyeluruh. Dampak dari adanya perubahan ini, penyelenggaraan pemerintahan di daerah tidak lagi ditangani secara sentralistik, tetapi lebih mengedepankan masyarakat dan pemerintahan di daerah, yang dilaksanakan dalam pola desentralisasi. Dengan pola ini, pemerintah kabupaten dan kota memiliki hak, kewajiban, tanggung jawab dan wewenang dalam menyelenggarakan administrasi publik yang sesuai dengan harapan dan keinginan masyarakatnya serta kepentingan daerah.

Penyelenggaraan pemerintahan yang bersifat desentralistik memerlukan adanya peningkatan kompetensi aparatur pemerintah daerah serta partisipasi masyarakat dalam penyelenggaraan pemerintahan daerah. Untuk itu dibutuhkan adanya perubahan perilaku segenap unsur penyelenggaraan pemerintahan serta masyarakatnya. Hal ini diperlukan, karena masyarakat menjadi faktor penting dalam sistem dan manajemen pemerintahan daerah. Peran masyarakat yang diwujudkan dalam bentuk aktivitas dan kreativitas masyarakat mengembangkan pola penyelengaraan pemerintahan yang efektif dan efisien, sesuai dengan tuntutan dan harapan masyarakat yang ada di daerah. Dalam disiplin ilmu dan sistem administrasi publik kontemporer, dijelaskan bahwa organisasi publik mempunyai fungsi, peranan dan kewajiban untuk menyelenggarakan pelayanan yang baik dan mampu memuaskan masyarakat (Thoha, 1995: 4).
Pada tataran empirik dapat dilihat secara kasat mata, adanya indikasi kuat kurangnya rasa percaya masyarakat kepada pemerintah. Hal ini disebabkan antara lain, oleh kurang puasnya masyarakat terhadap layanan yang diberikan oleh pemerintah. Kurang puasnya masyarakat ini dapat dilihat dari sikap yang dilakukan oleh masyarakat sebagai wujud rasa ketidakpuasannya, dari yang paling sopan dengan menyampaikan saran dan kritik kepada pemerintah melalui media cetak dan elektronik, sampai kepada cara yang kasar dengan melakukan orasi dan demonstrasi.

Memperhatikan kenyataan sebagaimana yang dikemukakan itu, maka upaya pemerintah untuk meningkatkan kinerjanya, adalah jawaban dari rasa ketidakpuasan masyarakat terhadap pemerintah. Dengan adanya tuntutan ini mendorong pemerintah daerah untuk melakukan perubahan-perubahan yang mendasar dalam menyelenggarakan pemerintahan di daerah.

Kenyataan yang dihadapi oleh masyarakat sekarang ini, bahwa pemerintah belum optimal dalam memberikan pelayanan kepada masyarakat. Aparat yang bertugas sebagai ujung tombak dalam memberikan pelayanan kepada masyarakat banyak yang tidak memahami filosofi, strategi dan teknik pemberian pelayanan kepada masyarakat. Salah satu penyebabnya adalah karena pemerintah bersifat monopoli dalam memberikan pelayanan kepada masyarakat, sehingga tidak ada kompetisi, hal ini menyebabkan kurangnya perhatian terhadap kompetensi aparat yang memberikan pelayanan.

Dalam rangka meningkatkan kinerja pemerintahan, terutama dalam hal memberikan pelayanan kepada masyarakat, maka sangat diperlukan adanya suatu sistem birokrasi pemerintahan yang rasional yang dapat melayani kebutuhan rakyat dengan maksimal dan terhindar dari hal-hal yang bersifat subyektif dan tidak rasional akibat adanya hubungan yang bersifat emosional serta memihak di dalam proses penyelenggaraan pemerintahan. Dalam hubungan dengan birokrasi pemerintahan daerah, yang tujuan utama birokrasi pada dasarnya adalah untuk menghasilkan sesuatu yang memiliki nilai secara cepat, tepat dan dengan biaya yang terjangkau atau ekonomis (Thoha, 1995: 4).

Jika organisasi pemerintahan daerah dapat ditata dengan mempertimbangkan dan menerapkan budaya organisasi yang sesuai 
dengan penyelenggraan pemerintahan di daerah, maka sejatinya tidak perlu ada pemerintah an didaerah yang tidak mampu menjalan fungsinya sekaligus memunuhi tuntutan masyarakat yang menuntut pelayanan pemerintahan seperti yang diharapkan.

\section{METODE}

Penelitian ini dilakukan dengan menggunakan metode penelitian kualitatif model interpretif, metode ini sesuai dengan model yang digariskan dalam paradigma constructivis, bahwa peneliti atau penulis berfungsi untuk menterjemahkan apa yang dikatakan oleh sasaran penelitian, subjek penelitian ini adalah birokrat pemerintahan daerah di Lampung sebagai informan kuncinya, sedangkan informan pokoknya adalah masyarakat yang berhubungan langsung dengan pelayanan pemerintahan di daerah. Data penelitian diperoleh melalui wawancara mendalam dan observasi partisipasi, validitas dan keabsahan data diperoleh dengan cara melakukan member check dan triangulasi baik pada data maupun sumber, termasuk dengan memperpanjang keikutsertaan, analisis data dilakukan sejak, sedang dan sampai semua data dilapangan diperoleh, semua data dianalisis dengan menggunakan model analisis interaktif, yakni rangkaian yang saling kait mengkait sejak penelitian dirancang diverifikasi dan ditarik kesimpulannya.

\section{HASIL DAN PEMBAHASAN}

Tulang Bawang diyakini pertama kali tertulis dalam catatan Cina sebagai satu kerajaan yang makmur bernama To-Lang P'o-Hwang (Tulang Bawang) di Sumatera. Catatan itu bersumber dari pedagang Cina yang bernama Fa-Hien pada pertengahan abad ke-4 Masehi. Disebutkan bahwa Kota Menggala yang terletak di tepi alur Sungai Tulang Bawang merupakan pusat perdagangan beragam komoditas, khususnya lada hitam.

Kabupaten Tulang Bawang yang dengan sebutan "Sai Bumi Nengah Nyappur" merupakan salah satu dari 10 (sepuluh) kabupaten dan kota yang ada di wilayah Provinsi Lampung. Kabupaten Tulang Bawang pada mulanya merupakan salah satu bekas Kecamatan Menggala yang berada di Kabupaten Lampung Utara. Dengan adanya perkembangan yang cukup pesat, bekas kecamatan tersebut ditingkatkan statusnya menjadi Pembantu Bupati Menggala dan kemudian ditingkatkan lagi menjadi Kabupaten Tulang Bawang berdasarkan Undang-Undang Republik Indonesia (No. 2 Tahun 1997) yang beribukota di Menggala. Saat ini Kabupaten Tulang Bawang secara administrasi terdiri dari 16 (enam belas) kecamatan definitif dan 228 (dua ratus dua puluh delapan) kampung dan kelurahan.

Secara geografis, luas wilayah Kabupaten Tulang Bawang 7.770,84 Km atau 22\% dari luas Provinsi Lampung (merupakan Kabupaten terluas di Provinsi Lampung), kerukunan kehidupan beragama sangat baik dan mayoritas penduduk di kabupaten ini beragama Islam. Semua diarahkan kepada pemantapan fungsi, peran dan kedudukan agama sebagai landasan moral, spiritual serta etika dalam kehidupan bermasyarakat, berbangsa dan bernegara.

Dalam adat masyarakat Lampung terdapat Perwatin Adat atau mufakat yang merupakan majelis tertinggi adat yang memutuskan segala macam masalah adat. Lembaga ini diketuai oleh seorang ketua yang disebut sebagai Penyimbang. Ada dua macam penyimbang yaitu Penyimbang Adat dan Penyimbang Pangkat. Penyimbang Adat adalah pemimpin berdasarkan garis keturunan dari para pendiri marga, sedang Penyimbang Pangkat adalah pemimpin yang membentuk kepenyimbangan tersendiri dengan syarat tertentu. Penyelenggaraan pemerintahan di Kabupaten Tulang Bawang didukung oleh Pegawai Negei Sipil (PNS) dan mitra pemerintah yaitu DPRD. Di Kabupaten Tulang Bawang telah terjadi pembauran antara penduduk asli dengan pendatang. Pembauran antar suku sangat berpengaruh terhadap nilai-nilai budaya yang menjadi pegangan ppenduduk asli maupun penduduk pendatang.

Hasil temuan juga menunjukkan bahwa dalam kategori tertentu misalnya kesamaan suku tidak selamanya menjadi faktor dominan dalam pemilihan pejabat, terutama pejabat yang memiliki fungsi dan posisi penting di pemerintahan daerah. Dengan kata lain, walaupun budaya Patron-Klien mewarnai birokrasi pemerintahan daerah, namun tetap diusahakan untuk tetap rasional. Hal ini tercermin dalam proses pemilihan sekertaris daerah di Kabupaten Tulang Bawang saat ini. 
Kepala daerah atau bupati di Kabupaten Tulang Bawang berasal dari Lampung dan bupati memutuskan untuk mengusulkan sekertaris daerah dari Lampung Abung yang kemudian terpilih. Dengan terpilihnya ia sebagai pejabat, maka sekertaris daerah harus menunjukkan kemampuan agar tidak mengecewakan bupati yang telah memberikan kepercayaan. Sekertaris daerah akan berusaha menjaga dan memelihara serta menunjukkan kemampuan dalam pelaksaanaan tugas-tugas birokrasi pemerintahan secara baik.

Semua peraturan yang berkaitan dengan hubungan, sistem, struktur dan pedoman penyelenggaraan pemerintahan yang baik dan benar menjadi sesuatu yang mutlak untuk ditegakkan. Upaya itu adalah guna mendapatkan dan menempatkan pegawai atau birokrat yang profesional pada jajaran birokrasi di pemerintahan, meskipun dengan dalih hubungan darah sekalipun, birokrasi bisa bekerja atas dasar profesionalitas yang memadai.

Aturan yang harus ditegakkan dalam penyelenggaraan pemerintahan di daerah diharapkan dapat pula sejalan dengan fenomena budaya lokal yang juga harus dimaknai secara bijak bagi birokrat yang berada di daerah. Pemahaman yang bijak terhadap budaya lokal serta kemampuan untuk memilih dan memilah budaya positif yang dapat menunjang kinerja birokrasi tentu harus dipahami oleh semua komponen masyarakat termasuk oleh para birokrat yang merupakan ujung tombak birokrasi.

Masalah yang timbul adalah seringkali keberadaan budaya lokal cenderung dipersepsi positif semuanya. Padahal dalam kategori tertentu masih ada celah yang dimiliki budaya lokal untuk melihat seseorang bukan atas dasar kemampuannya melainkan atas dasar strata atau keturunannya, sehingga mereka yang dianggap tidak memiliki asal-usul yang jelas seringkali dianggap hina meski mereka memiliki kemampuan profesional

Ada perbedaan pandangan masyarakat dan birokrat dalam melihat dan memahami terjadinya budaya organisasi (baik jaringan, upahan, Fragmen maupun komunal) meskipun secara mendasar memiliki pemahaman yang sama atas tiga hal yaitu terjadinya budaya Patron-Klien lebih dimungkinkan terjadi karena adanya hubungan kekeluargaan, pertemanan dan kesamaan suku.
Tetapi, untuk kategori lain misalnya tentang kesamaan kepentingan, kesamaan prinsip atau ideologi, kesamaan alumni serta adanya rasa saling percaya maupun adanya saling pengertian serta hubungan emosional cenderung hanya dirasakan oleh para birokrat pemberi maupun penerima pelayanan dibandingkan masyarakat yang menerima pelayanan.

Hasil temuan lainnya bahkan mengisyaratkan bahwa apa yang dimaknai masyarakat. secara umum ternyata sedikit berbeda dan bahkan ditemukan kategori yang jauh lebih luas dari konsep budaya organisasi, artinya antara sosialitas dan solidaritas, kadang berjalan sering, kadang dipisahkan, yang menyatakan hubungan dalam pekerjaan terjadi karena adanya saling pengertian dan hubungan emosional antara atasan dan bawahan.

Ini bisa juga disebabkan adanya kepemilikan sumberdaya serta terjadinya pertukaran atas sumberdaya antara masyarakat, pegawai dan pemerintah daerah sebagai pemilik kekuasaan, pemerintah dan pegawai yang mempunyai kedudukan, jabatan dan materi, serta kepemilikan tenaga, dukungan dan loyalitas terhadap organisasi bagi pegawai, dengan pertukaran dan interaksi yang resiprokal serta unsur budaya lokal yang menyertai terjadinya budaya itu, maka budaya organisasi di pemerintahan daerah Kabupaten Tulang Bawang Lampung mampu mengkombinasikan keempat tife budaya organisasi yaitu budaya jaringan, budaya upahan, budaya fragmen dan budaya komunal

Akan tetapi, Pengukuran kinerja pemerintah tidak cukup hanya dengan menilai indikatorindikator yang melekat pada penyelenggaraan pemerintahan seperti efisiensi dan efektivitas kerja, namun harus diamati juga dari indikatorindikator yang melekat pada pengguna jasa, seperti kepuasan pengguna jasa, akuntabilitas aparatur, dan responsivitas. Penilaian kinerja dari sisi pengguna jasa menjadi sangat penting karena pemerintah seringkali menggunakan kewenangan monopolis sehingga para pengguna jasa tidak memiliki alternatif sumber pelayanan. Ketika pelayanan yang diberikan pemerintah tidak memuaskan pelanggan, maka pengguna jasa tidak dapat berbuat banyak karena tidak ada pilihan lain, sehingga puas tidak puas masyarakat terpaksa menerima apa adanya. 
Kesulitan mendasar dalam penilaian kinerja pemerintah adalah terbentur pada masih kaburnya visi dan misi birokrasi pemerintahan, bahkan juga disebabkan oleh terlalu multidimensionalnya tujuan dan misi pemerintah sehingga sulit untuk dilakukan penilaian. Di sisi lain pemerintah sebagai pelayan publik juga mengalami kesulitan dalam merumuskan misi yang jelas. Akibatnya ukuran kinerja pemerintah di mata masyarakat juga berbeda-beda.

Untuk mengetahui dan mendalami apa sebenarnya birokrasi itu maka tidak dapat dilepaskan dengan pembahasan tentang organisasi. Hal ini disebabkan karena birokrasi pada dasarnya adalah merupakan salah satu bentuk dan organisasi formal sebagaimana yang ada pada jajaran pemerintahan. Pengertian organisasi menurut Hodge dan Anthony (1988: 7) mengatakan bahwa organisasi merupakan sistem sosial dan kerjasama yang didesain untuk mempertinggi usaha-usaha individual yang diarahkan pada pencapaian tujuan. Dalam organisasi pula tumbuh seperangkat nilai dan norma, nilai dan norma itu pula yang dipahami oleh Pemerintayh Daerah sebagai penyelenggara pemerintah Daerah, Pegawai sebagai aparatur pemerintah dan masayarakat yang berhubungan dengan pemerintah daerah.

Di Kabupaten Tulang Bawang Lampung nilai yang menyertai kinerja pemerintahan juga dapat ditemukan meliputi dua jenis nilai. Yakni : nilai yang mendukung (espaused Values), nilai itu telah dibuat standar oleh organisasi pemerintah daerah berpedoman pada nilai yang ditetapkan sebagai sebuah organisasi npemerintahan dan dinyatakan secara ekslisit, nilai itu dipilih organisasi.

Dan nilai lain yang dianut, adalah nilai lain yang diperankan (enacted Values), ini adalah nilai dan norma yang ditunjukan dalam perilaku pegawai, nilai inilah yang memenuhi ranah budaya organisasi di Kabupaten Tulang Bawang Lampung. Meski dikebanyakan organisasi termasuk organisasi pemerintahan terdapat jurang yang dalam antara espaused values dan enacted values, tetapi penelitian ini menemukan nyaris tiada jurang itu di organisasi pemerintahan Kabupaten Tulang Bawang Lampung < ini artinya Budaya organisasi yang ditandai oleh pemahaman terhadap nilai telah ditunjukkan dalam organisasi pemerintah Daerah Tulang Bawang Lampung.
Seperti kebanyakan organisasi lainnya, Pemerintaah Daerah Tulang Bawang Lampung juga memiliki sistem nilai, pola dan argumentasi kedaerahan yang dianut sebagai sitem nilai dan hal ini juga yang mendukung pencapaian tujjuan organisasi menjadi mudah sehingga budaya organisasi dalam banyak kategori terwujudkan dalam sistem pemerintahan di Kabupaten Tulang Bawang Lampung.

Budaya serupa juga dimiliki oleh berbagai daerah di Indonesia termasuk di Lampung tempat penelitian ini dilaksanakan. Nilai-nilai dasar yang menjadi pegangan pokok masyarakat suku Lampung terkandung dalam untaian kalimat "Tando now ulun Lappung, wat piil, you balak piil ngemik malou ngigau diri, ulah now berjuluk you be-adek, illing mewari ngejuk ngajuk nemui nyimah ulah nou pandai you nengah you nyappur, nyubali jejamow, begawiy balak, sakai sambayan". Ungkapan itu diterjemahkan secara bebas oleh Rusidi ${ }^{1}$ sebagai "tandanya orang lampung, ada piil ia berjiwa besar mempunyai malu, menghargai diri, karena lebih, bernama besar dan bergelar, suka bersaudara, beri memberi terbuka tangan, ia ramah suka bergaul, mengalah bersama pekerjaan besar tolong menolong". Falsafah hidup ini secara umum terdiri dari lima unsur pokok yaitu :

1. Piil artinya keharusan hidup bermoral tinggi, berjiwa besar, tahu diri dan kewajiban.

2. Sakai Sambayan artinya keharusan hidup berjiwa sosial, tolong menolong tanpa pamrih dan gotong royong.

3. Nemui Nyimah artinya keharusan berlaku sopan santun terhadap sesama anggota masyarakat, terbuka tangan baik moril maupun materil kepada siapa saja.

4. Nengah Nyappur artinya keharusan ikut bergaul dalam masyarakat, ikut memberikan sumbangan pikiran, pendapat dan inisiatif bagi kebaikan hidup bersama.

5. Berjuluk-beadek artinya keharusan berjuang meningkatkan derajat kehidupan, bertata tertib dan bertata krama.

Budaya Piil menekankan kepada setiap individu untuk mengetahui, memiliki dan mengamalkan suatu prinsip, sifat atau sikap yang

\footnotetext{
${ }^{1}$ dalam Kausar. 2006
} 
sangat menjunjung tinggi harga diri, baik untuk dirinya sendiri maupun keluarganya ${ }^{2}$.

Hakekatnya seseorang kalau sudah kehilangan harga diri, maka sudah hilanglah kredibilitas diri sendiri dan keluarganya, maka seseorang itu tidak lagi dianggap oleh orang lain atau dibuang dari masyarakatnya. Seseorang dengan memiliki harga diri akan menjaga kredibilitasnya dengan sempurna dan menghindari perilaku yang tercela atau merugikan orang lain. Termasuk untuk berbuat tidak adil, korupsi, kolusi dan nepotisme, serta perbuatan yang melanggar peraturan lainnya.

Piil masih dipegang kuat oleh individuindividu maupun kelompok kekerabatan. Seringkali terjadi Piil ini bisa menimbulkan pembunuhan atau rusuh sekampung yang kadang-kadang disebabkan oleh kekecewaan atau rasa malu, maka dari itu kekecewaan sangat dihindari oleh setiap individu atau kelompok kekerabatan yang ada (Syamsudin, 1987: 30).

Budaya Piil jika berkembang dan dilaksanakan secara positif akan menimbulkan suatu sikap saling menghargai dan berbuat adil dalam menjalankan peran dan fungsi masingmasing. Manakala sikap ini mewarnai individuindividu yang berada dalam birokrasi pemerintah daerah tentunya akan dapat berjalan dengan baik karena masing-masing orang memiliki harga diri dan tanggung jawab, maka akan sangat dibutuhkan dalam melaksanakan tugas sebagai aparatur yang melayani masyarakat. Sikap individu ini kalau menjadi sikap bersama organisasi birokrasi pemerintah daerah, secara tidak langsung akan mempengaruhi kinerja birokrasi pemerintah daerah

Dalam kategori keyakinan, ada tuntutan yang stabil antara menjalankan tugas dan berinteraksi dengan masyarakat, temuan ini juga sejalan dengan teori hirarki keyakinan yang pernah dikemukakan oleh Milton Rokeach yang dikenaal dengan " Rokeach's Beliefs Hierarch" (Littlejohn: 1995 :143). Di Tulang Bawang Lampung organisasi pemerintahannya menerapkan juga budaya organisasi dimana seluruh keyakinan, sikap dan nilai harus memberi warna kinerja dan berkontribusi dalam pelayanan birokrasi yang diberikan, artinya argumentasi budaya organisasi

\footnotetext{
${ }^{2}$ lihat Fachruddin dalam Kausar, 2006
}

didukung oleh keyakinan terhadap tatanan nilai yang berlaku di daerah, meski semua orang memiliki sistem keyakinan, sikap dan nilai yang sangat teratur dalam hierarki, maka semuaq ahal itulah yang menjadi panduan dalam berperilaku, termasuk dalam organisasinya.

Temuan ini tentu saja menepis anggapan bobroknya kinerja pemerintahan di daerah yang lebih mengutamakan keberhasilan individual dan dipenuhi korupsi dan nepotisme, hasil penelitian ini juga dapat mencerahkan pemerintahan daerah lain bahwa begitu pentingnya membangun budaya organisasi dalam tiap model dan pelayanan birokrasi yang diterapkan dan diwujudkan dalam masayarakat.

Dalam perspektif teori pertukaran perilaku birokrasi, khususnya birokrasi pemerintah daerah kabupaten, dapat dicermati adanya hubungan sosial yang secara umum mempunyai ciri sebagai bentuk organisasi sosial. Sebagai organisasi sosial, maka birokrasi pemerintah daerah dianggap sebagai jaringan dari interaksi sosial yang terorganisir, atau merupakan suatu tindakan yang tertata melalui aktivitas sosial yang terkait antara satu dengan lainnya (Bertrand, 1972: 3).

Aktivitas sosial antara birokrasi pemerintah daerah dengan kelompok sosial lainnya, dengan masyarakat misalnya, saling terkait karena birokrasi merupakan suatu organisasi publik yang mempunyai tugas dan fungsi untuk memberikan pelayanan kepada masyarakat. Dalam lingkup organisasi birokrasi pemerintah daerah yang menyelenggarakan pemerintahan di daerahnya, menurut pendekatan kesisteman, maka keluaran yang ada adalah pelayanan kepada masyarakat di daerah tersebut. Birokrasi pemerintah daerah sebagai provider atau jasa pelayanan kepada masyarakat, sedangkan masyarakat adalah konsumen atau penerima jasa pelayanan. Dengan demikian, organisasi pemerintah daerah adalah suatu bentuk jaringan dari interaksi sosial terorganisir yang mampu menggerakkan sumberdaya yang ada dan melingkupi pemerintah daerah

\section{SIMPULAN}

Tiap organisasi, termasuk organisasi pemerintahan telah memiliki standar model dan budaya organisasi snediri, tetapi organisasi yang mampu menempatkan dan menelisik seperti apa budaya organisasi yang dijaalankan pastilah akan memperoleh dukungan, dan bahkan penghargaan 
yang tidak boleh dianggap enteng. Artinya hanya organisasi yang berbudaya organisasi sesuai dengan harapan tidak hanya organisasinyalah yang bisa memberi inspirasi kepada masyarakatnya, dan pemimpinnya juga atau kepala pemerintahannya akan menjadi sosok yang berkharisma sekaligus menjadi inspirasi bagi masyarakatnya.

Di kabupaten Tulang Bawang Lampung, dapat ditelisik antara budaya organisasi yang bertipe jaringan, upahan, Fragmen dan komunal, ternyata dilakukan secara bervariasi dalam birokrasi pemerintahan, hal ini mengisyaratkan tidak ada satu tipe yang diunggulkan dari tipe lainnya, artinya semua tipe bisa bergerak sejalan dan beriringan dengan pada saat apa, bagaimana dan kapan tujuan organisasi hendak diwujudkan.

Disisi lain semua nilai dan keyakinan yang diyakini baik oleh pemerintah daerah maupun oleh masyarakat di daerah itu juga telah menunjukkan adanya nilai yang mendukung (espaused values) dan nilai yang diperankan (enacted values) termasuk nnilai budaya lokal yang dikenal dengaqn budaya piil pasenggiri. Semu itu dapat diupayakan menjadi bagian dari kinerja birokrasi di daerah, bahkan berdasrkan keyakinan, birokrasi pemerintahan daerah juga sudah mampu memilah dan memilih bagaimana medlakonkan pekerjaan organisasi tanpa mengabaikan interaksi dengan masyarakat.

Berdasarkan kesimpulan itu disarankan
adanya upaya membangun birokrasi
pemerintahan daerah dengan menguapayakan
budaya organisasi yang sesuai dengan tujuan
dimana organisasi pemerintahan daerah itu
ditetapkan dan bagaimana rekayasa birokrasi
yang standar secara nasional mampu
mempertimbangkan nilai dan keyakinan yang
dianut aparatur pemerintahan didaerah dalam
menjalankan kinerja organisasinya.

Berdasarkan kesimpulan itu disarankan budaya organisasi yang sesuai dengan tujuan dimana organisasi pemerintahan daerah itu ditetapkan dan bagaimana rekayasa birokrasi yang standar secara nasional mampu menjalankan kinerja organisasinya.

\section{DAFTAR PUSTAKA}

Bertrand, A. L. 1972. Social Organization: $A$ General Systems and Role Theory Perspective. Philadelphia: F. A. Davis Company.

Fachruddin,dkk. 1996. Daya Tarik dan Pengelolaan Agrowisata. Jakarta : Swadaya

Kausar. 2006. Budaya Patron-Klien Dalam Prilaku Birokrasi Di Daerah. Disertasi. Bandung:Unpad.

Littlejohn, Stephen W., 1996. Theories of Human Communication. Edisi ke 5, Belmont California, Wadsworth.

Pace, R Wayne et al 1998. Organizational Communication, Foundations for Human Resource Development, New Jersey. Prentice. Hall.Inc

Rasyid, M. Ryaas. 1997. Makna Pemerintahan Tinjauan Dari Segi Etika Dan Kepemimpinan. Jakarta: P.T Yarsif Watampone.

Thoha, Miftah, 1995. Kepemimpinan dalam Manajemen Suatu Pendekatan Perilaku. Jakarta. PT Raja Grafindo Persada.

Robbins. S. 2003. Prilaku Organisasi (terj). Jakarta: gramedia

Hodge, B.J., \& Anthony, W. P. 1988. Organizational theory. Boston: Allyn \& Bacon

UU No 2/1997 Tentang Pembentukan Kabupaten Tulang Bawang

UU No 22/ 1999 Tentang Pemerintahan Daearh

UU No 32/2004 Tentang Pemerintahan Daerah 